\title{
GCU
}

Glasgow Caledonian

University

University for the Common Good

\section{Processes of community-led social enterprise development: learning from the rural context}

Munoz, Sarah-Anne; Steiner, Artur; Farmer, Jane

Published in:

Community Development Journal

DOI:

$10.1093 / \mathrm{cdj} / \mathrm{bsu} 055$

Publication date:

2014

Document Version

Author accepted manuscript

Link to publication in ResearchOnline

Citation for published version (Harvard):

Munoz, S-A, Steiner, A \& Farmer, J 2014, 'Processes of community-led social enterprise development: learning from the rural context', Community Development Journal, vol. 50, no. 3, pp. 478-493.

https://doi.org/10.1093/cdj/bsu055

\section{General rights}

Copyright and moral rights for the publications made accessible in the public portal are retained by the authors and/or other copyright owners and it is a condition of accessing publications that users recognise and abide by the legal requirements associated with these rights.

Take down policy

If you believe that this document breaches copyright please view our takedown policy at https://edshare.gcu.ac.uk/id/eprint/5179 for details

of how to contact us. 
Processes of Community-Led Social Enterprise Development: Learning from the Rural Context

Sarah-Anne Munoz, Centre for Rural Health, UHI, Inverness, IV2 3JH, Scotland, UK Artur Steiner, Rural Society Research Team, SRUC, Edinburgh, EH9 3JG, Scotland, UK Jane Farmer, Faculty of Health Sciences, La Trobe University, Bendigo, Victoria, Australia 


\begin{abstract}
Drawing on research carried out in rural Scotland, the paper describes the role of supported community action in the process of generating rural social enterprise. The focus is on whether, and if so how, rural communities can be supported through a facilitated process to create social enterprises as service providers. Using results from the analysis of four community case studies involved in an action-research process to develop social enterprise, the paper identifies the community capabilities and entrepreneurial skills needed to create social enterprises as rural communitybased service providers. These processes, skills and capabilities are presented in the form of a development model. This model is a diagrammatical representation of the thematic analysis of qualitative material and is used to highlight similarities and differences in how the development process took place in four case study communities. The final section of the paper presents conclusions and implications identifying the contribution of the study to generating understanding about rural community social enterprises for service provision and the processes associated with their creation.
\end{abstract}




\section{Introduction}

Over the last two decades, UK policy discourse has increasingly referred to social enterprise organisations as an important component of economic development, highlighting their role in providing services to communities (DTI, 2002, 2006; The Conservative Party, 2010; Cabinet Office, 2010). Social enterprises are defined as organisations that operate independently of the state and, rather than being driven by the need to maximise profit for shareholders and owners, are focused on investment and surplus reinvestment for social, environmental or community good (DTI, 2002, 2006). Rural locations, have been noted as potentially offering the ideal place for establishing and operating social enterprise but might be simultaneously perceived as deprived of resources and presenting 'distinctive challenges' to their development (Steinerowski et al., 2008a).

The UK governments have promoted and supported social enterprise through direct funding (Kerlin, 2006) business support (Hines, 2005) and, increasingly, through procuring goods and services from social enterprise organisations (Simmons, 2008). Within UK policy discourse it is suggested that citizens will take greater responsibility for organising services traditionally delivered by the state with communities, neighbourhood groups and existing voluntary organisations doing things 'for themselves' (The Conservative Party, 2010). Yet there is little practical guidance on how this might happen and a gap in knowledge relating to the processes of how community social enterprise organisations may emerge as service providers within different types of social and geographical context exist.

To avoid policy fostering an uneven geography of community service provision, the process associated with transferring elements of power and engaging communities in delivering services through social enterprises needs to be better understood. It is essential 
to understand which resources and capacities communities need to employ in order to create social enterprises as service providers. These resources and capacities may not be present to equal extents within different communities and may need to be fostered and supported by, for example, local authorities, regional development agencies and national government (Steiner and Markantoni, 2013). The model of social enterprise development presented in this paper contributes to increasing understanding in this theme by identifying the processes involved in facilitating community social enterprise in rural areas.

Service co-production and Social Enterprises Increasingly, the UK public sector is looking to deliver services through co-production approaches that involve contracting to social enterprises (Ridley-Duff, 2007). Co-production has been conceptualised as a way of transforming public services and addressing current challenges by developing a collaborative approach between service users and providers which involves "users and professionals working together to design and deliver public services in equal partnership" (Boyle and Harris, 2009, p.;11). Within this context, social enterprises and other nonpublic sector organisations are increasingly looked on to provide a proportion of previously state-provided services (Ridley-Duff, 2007). Policy suggests that this will lead to the development of individual capacity, increased community confidence and social capital (Needham, 2007; Boyle et al., 2010; Bertotti et. al., 2012). However, evidence is lacking on the achievement of such goals through social enterprise and the skills and capabilities needed to develop such organisations. Although previous research has considered the processes of social enterprise creation and sustainability there is a paucity of work that considers how these factors may play out in the rural community context.

\section{The development of community-led Social Enterprises}


Case study work on social enterprise development points to some general trends in the process of creation and sustainability. Development work often starts with idea generation associated with an individual socially entrepreneurial leader. As the organisation grows, the leader has to employ strategies to balance social and economic goals through activity such as drawing in resources (Teasdale, 2012); developing effective marketing capabilities (Liu and Ko, 2012) and fostering collaborations (Nguyen et al., 2012). De Vasconcelos and Lezana (2012) describe this as moving from processes of "action" towards "visibility" and "networking". Sustainability is built through a mixture of strategies that work to embed the legitimacy of the organisation as a trading entity (Ko, 2012). However, previous work has tended to focus on the organisational life-cycle (Chen, 2011) rather than the processes leading up to the point at which the social enterprise starts to trade. Research has looked at the types of business support that are useful for social entrepreneurs (Phillips, 2006) but there has been less consideration of whether it is possible to foster more widespread adoption of a community social enterprise approach to co-productive service delivery. Thus, this paper looks at whether communities can be supported to do this by taking the particular example of the rural context.

\section{Rural context -threat or opportunity?}

Knowledge about community social enterprise development processes in the rural context is largely scattered, despite the characteristics of such areas suggesting the potential for social enterprise creation (e.g. dense social networks and high levels of civic participation; Anderson and Jack, 2002; Dale and Onyx, 2005;). 'Traditional challenges' of rural areas may also provide opportunity for social enterprise whilst concurrently necessitating particular support for organisational establishment, e.g. dispersed settlement patterns, low population densities and aging populations (Farmer et al., 2008). Previous case study work has identified the important social benefits that can be generated by rural social enterprise, e.g. combating social isolation and accessibility issues in remote areas 
(O'Shaughnnessy et al., 2011). However, previous studies indicated a number of challenges associated with rural social enterprise development such organisational capacity issues due to a limited number of people in rural communities with appropriate skills and willingness (OECD, 2008) to engage in their development and management. Rural citizens may resent the imposition of further service provision onto themselves and demand state provided services - associating (wrongly perhaps) social enterprise provision with an erosion of rural services (Farmer et al., 2008). Further, factors such as dispersed populations, limited markets and existing high levels of volunteering within rural communities (Steinerowski et al., 2008a) may act as barriers towards the engagement of citizens in co-production through social enterprise. These call for testing current policies that imply that service co-production through social enterprises is a feasible concept in rural locations.

This paper thus presents research that considered how rural communities could be supported to collaboratively develop social enterprise for service co-production. This helps us to understand more about the processes of community social enterprise creation in rural communities to ensure that these areas do not 'lose out' as a result of non-state service provision. It also develops a clearer picture of what is needed, particularly within the rural context, in order to facilitate community social enterprise development and service co-production. As rigorous evidence on how rural social enterprises are created is lacking, we aim to identify processes through which community social enterprise creation can be supported in rural areas. The article shows critical junctions where things can go wrong and key features of process for community members and other actors involved in creating social enterprises. 


\section{Methodology}

This paper presents the process of developing community social enterprises in rural areas by taking the case study of the Older People for Older People (040) project. Qualitative materials gathered during the 040 project were subject to thematic analysis and the resultant themes are presented here within a process model of community social enterprise development.

040 was a European Union project conducted between 2007 and 2011 and the findings discussed in this paper are drawn from the Scottish component of the study. 040 aimed to investigate whether, and if so how, it is possible to harness the energies of older people (defined as those aged 55 and over; Scottish Executive, 2007) in the development of community social enterprises that would provide older people's services. 040 focused on older people because the ageing population is a major challenge facing our rural communities and, therefore, it is important to understand whether older people could create and run community-based social enterprises for service provision or if the coproduction agenda might disadvantage such communities and populations.

040 adopted an action research approach which was used to work with community members to create community social enterprises, whilst collecting qualitative information on the processes involved (Koshy, 2009; Fletcher, 2006). This provided a framework within which 040 action researchers (called Project Managers) engaged in direct, practical activities with communities but also reflected on the 'practice' of community social enterprise facilitation (Whitehead and McNiff, 2001). Thus, the project managers were involved in a continuous process of reflection and refinement of approach and activities.

The Project Managers worked with community members to develop social enterprises of the type commonly conceptualised within UK policy and practice as potential health/wellbeing service providers with positive social and economic impacts. This type of social 
enterprise has several characteristics: it is community-led; has a social goal; is engaged in trade and adopts a co-productive approach to service delivery. The Project Managers did not set out to impose this option on communities, but to work with them to understanding whether it would be feasible for them to adopt and develop such a model. A community development approach was taken in which the Project Managers worked to support community members to create social enterprises that address local needs (Ogilvie, 2012). This approach was appropriate to the project's aim of testing whether, and if so how, rural communities could create and run social enterprises for older people's service delivery. Thus, the Project Managers started with community engagement and worked through the facilitation of community social enterprise development in a mentoring capacity. Given various contextual factors such as prevailing political milieu, different communities' readiness and willingness to get involved in service delivery, and the types of services they chose to develop, a range of organisational types emerged across the communities involved.

In order to capture information on this process, an activity reporting template was completed by Project Managers on a monthly basis. Additionally, they were interviewed at six monthly intervals throughout the project. The interviews were carried out by an external evaluator, who carried out thematic analysis and reported findings to the project team. Researchers not involved in the social enterprise facilitation process (i.e. not Project Managers) collated the activity reports, which were then subject to thematic analysis managed within N-Vivo software. The thematic analysis focused on identifying the role of the Project Managers and community members within the creation and development of social enterprise organisations; the different skills and knowledges that were drawn on and the challenges faced. The aim of this analysis was to identify the processes, stages, skills and capabilities involved in the social enterprise development process. The codes developed included both emergent themes and socially entrepreneurial processes, roles and skills highlighted in existing literature (e.g. Zahra et al., 2009). In addition, the 
researchers included pertinent findings from the external evaluator's interviews. The themes were then validated through in-depth discussion with the 040 Project Managers.

The 040 Project Manager worked with four communities that were suggested as potential sites for community social enterprise development by a local Steering Committee with membership from the local council, community groups, government agencies and existing social enterprises. The selection was based on a range of factors, including current service delivery issues and the potential impact of social enterprise creation not only on older people but the community as a whole. The Project Manager reflected that the communities were "a mix of active and more disadvantaged communities that funders wanted to help" (Project Manager's Project Diaries, 2009 - 2011). Three of the communities are 60 to 100 miles away from the nearest city and have less than 500 citizens. One community, with a population of around 4,000, is located within 14 miles to the nearest city.

\section{Findings}

\section{Community Social Enterprise Development}

At the beginning of the 040 project, an action research framework was designed in order to structure the development of supported rural community social enterprises as service providers. This framework was based on the principles of community development to engage participants in the development of social enterprises (Figure 1). 


\section{Figure 1. The 'ideal' development process vision at the start of the 040 project.}

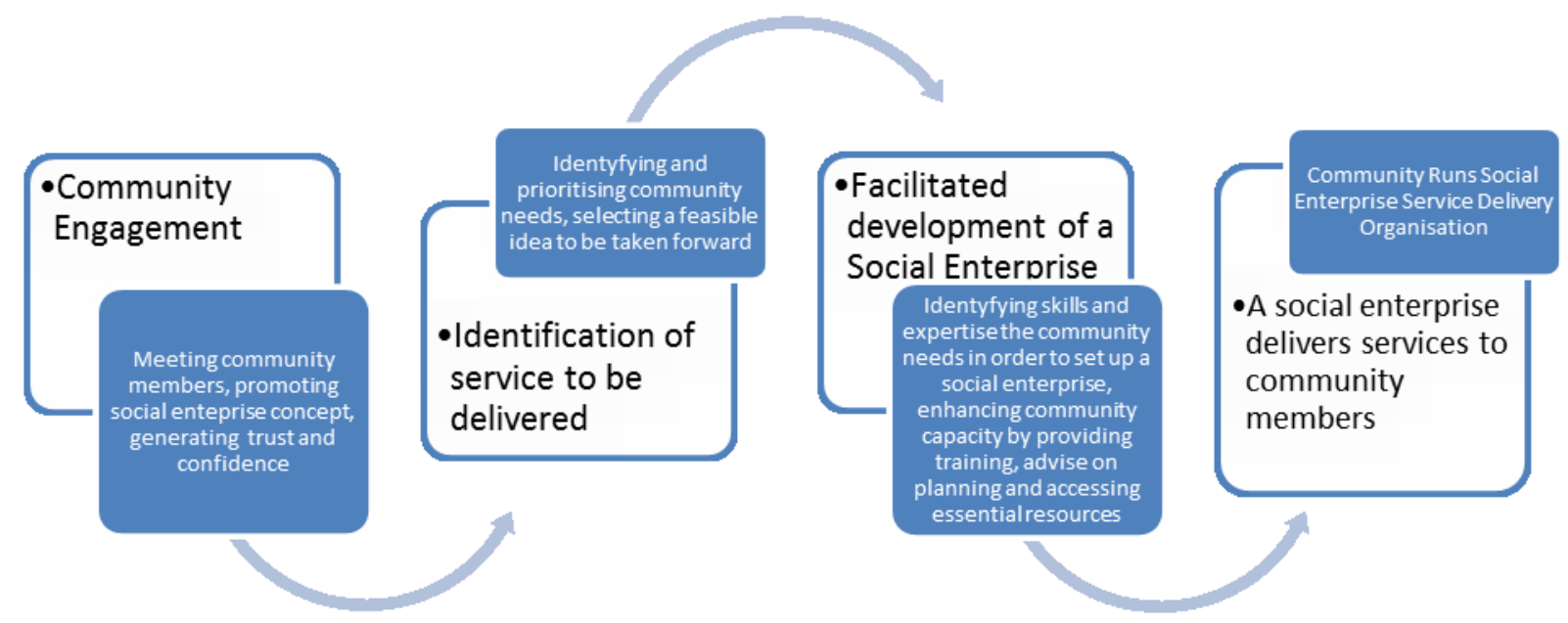

Figure 1 represents how we thought an 040 social enterprise would be created - by initially involving a community with the idea of designing and delivering services for themselves and moving towards delivery itself. It was anticipated that Project Managers would meet community members, attend events, hold meetings and publicise the concept of 040 in order to bolster community confidence and harness enthusiasm. As community members engaged with the concept of community social enterprise, it was thought that they would identify local service needs and select particular initiatives to focus on and take forward. At this stage, it was expected that the 040 Project Managers would offer support by acting as community mentors and assisting in the identification of the skills needed to take ideas forward. It was thought that the engagement process would result in community action or entrepreneurship in which momentum is generated and a social enterprise organisation established. Community members would take on various roles in running the organisation and Project Managers provide help with business planning, accessing resources and training. Finally, the 040 organisations would start to deliver services to the community and ultimately become self-sustaining.

It can be seen that this broad facilitation process included scope for each community to 
identify a locally important service delivery issue and develop a locally appropriate solution to it. Within the project, this proved to be an organic, complex process and each local project evolved a different service type (see Appendix 1). The pathways to social enterprise creation varied in nature and also in timescale between the communities. Although the communities required different amounts of time to develop a social enterprise, patterns become evident across the communities in terms of the processes that they went through. The patterns were captured in a model that represents the process of social enterprise development (see Figure 2).

\section{A Model of the Processes of Generating Rural Community Social Enterprise}

By examining the process of community social enterprise creation in each community alongside the thematic analysis of Project Manager reporting, it has been possible to identify the five main stages of supported rural community social enterprise creation: stage 1-legitimacy; stage 2-needs/opportunity recognition; stage 3-group coalescence; stage 4-organisational establishment; stage 5-social enterprise operates. 
Figure 2. Five Stages of Community Social Enterprise Development Process in Rural Context.

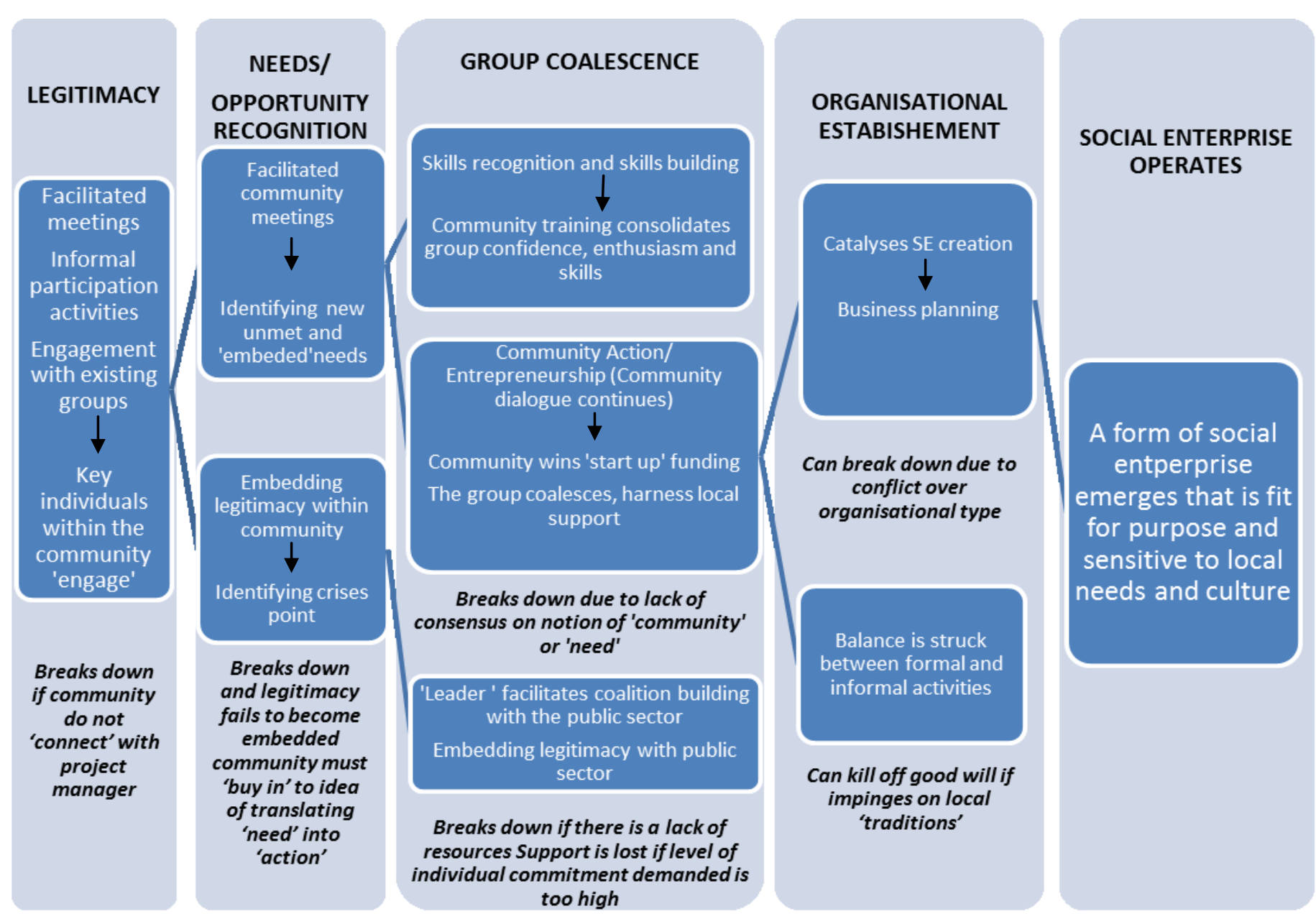


As presented in Figure 2, involved facilitated community engagement - thus, it is necessary to consider both the roles played by community members and our Project Manager. Table 1 outlines the roles played by these key actors throughout the process. The following sections of the paper discuss these stages in more detail and show how the action research/community development approach taken by the project has generated new knowledge on whether/how rural communities can be supported to develop social enterprise service delivery organisations. 
Table 1. Role of Community Members and Catalyst Figure in Community Social Enterprise Development in Rural Context.

\begin{tabular}{|c|c|c|c|c|}
\hline $\begin{array}{l}\text { Main Stages of } \\
\text { Development }\end{array}$ & $\begin{array}{l}\text { Community } \\
\text { Members' Role }\end{array}$ & $\begin{array}{l}\text { External } \\
\text { Catalyst's Role }\end{array}$ & $\begin{array}{l}\text { Elements of the Development } \\
\text { Process }\end{array}$ & $\begin{array}{l}\text { Potential Blocks to the } \\
\text { Process }\end{array}$ \\
\hline Legitimacy & $\begin{array}{l}\text { Engaged } \\
\text { community } \\
\text { members }\end{array}$ & $\begin{array}{l}\text { Leader, confidence } \\
\text { builder }\end{array}$ & $\begin{array}{l}\text { Facilitated community } \\
\text { meetings } \\
\text { Informal participation in } \\
\text { community activities } \\
\text { Engagement of Catalyst with } \\
\text { existing community groups } \\
\text { Key community members } \\
\text { engage with the concept of co- } \\
\text { production and social } \\
\text { enterprise }\end{array}$ & $\begin{array}{l}\text { Community do not connect } \\
\text { with the Catalyst } \\
\text { Community do not like the } \\
\text { idea of social enterprise or } \\
\text { co-production } \\
\text { Community see no need to } \\
\text { get involved in social } \\
\text { enterprise or co-production }\end{array}$ \\
\hline $\begin{array}{l}\text { Needs and/or } \\
\text { opportunity } \\
\text { recognition }\end{array}$ & $\begin{array}{l}\text { Community } \\
\text { representatives }\end{array}$ & Facilitator & $\begin{array}{l}\text { Identification of various forms } \\
\text { of need, e.g. new and unmet, } \\
\text { embedded } \\
\text { Community dialogue } \\
\text { Identification of crisis points } \\
\text { Legitimacy of social enterprise } \\
\text { and co-production is embedded } \\
\text { within the community }\end{array}$ & $\begin{array}{l}\text { Legitimacy fails to become } \\
\text { embedded in the } \\
\text { community } \\
\text { Lack of 'buy in' to translate } \\
\text { need into action }\end{array}$ \\
\hline $\begin{array}{l}\text { Group } \\
\text { coalescence }\end{array}$ & $\begin{array}{l}\text { Developing and } \\
\text { emerging leaders } \\
\text { and volunteers }\end{array}$ & Mentor, networker & $\begin{array}{l}\text { Skills recognition and skills } \\
\text { building } \\
\text { Community dialogue feeds into } \\
\text { action and entrepreneurship } \\
\text { Coalescence of group identity } \\
\text { and ability to take forward the } \\
\text { development process, e.g. } \\
\text { training, funding }\end{array}$ & $\begin{array}{l}\text { Lack of resources } \\
\text { Key individuals in the public } \\
\text { sector fail to engage with } \\
\text { the concept } \\
\text { Civic-public discourses are } \\
\text { not bridged by the Catalyst } \\
\text { or community members }\end{array}$ \\
\hline $\begin{array}{l}\text { Organisational } \\
\text { establishment }\end{array}$ & $\begin{array}{l}\text { Staff and } \\
\text { volunteers within } \\
\text { an organisational } \\
\text { structure }\end{array}$ & Mentor, networker & $\begin{array}{l}\text { The group harnesses local } \\
\text { support } \\
\text { A social enterprise is created } \\
\text { and business planning } \\
\text { undertaken } \\
\text { A balance is struck between } \\
\text { informal local volunteering } \\
\text { cultures and formal social } \\
\text { enterprise structures }\end{array}$ & $\begin{array}{l}\text { Individual levels of } \\
\text { commitment required are } \\
\text { too high } \\
\text { Conflict over the type of } \\
\text { organisational type to be } \\
\text { adopted } \\
\text { Can kill off good will if it } \\
\text { impinges on local } \\
\text { volunteering 'traditions' }\end{array}$ \\
\hline $\begin{array}{l}\text { Social Enterprise } \\
\text { Operates }\end{array}$ & $\begin{array}{l}\text { Staff and } \\
\text { volunteers within } \\
\text { an organisational } \\
\text { structure }\end{array}$ & $\begin{array}{l}\text { Distanced advice- } \\
\text { giver }\end{array}$ & & \\
\hline
\end{tabular}

\section{Stage 1-Legitimacy}

Analysis of the facilitated community social enterprise development process within the project revealed that before any organisational development began, community members had to be convinced of the legitimacy of a community-run social enterprise as a service provider. There are various kinds of legitimacy that are central to the process of social enterprise development. Different actors need to engage with the idea that a community 
social enterprise is a viable organisation to design and deliver services. This legitimacy must be embedded within the community that will provide or receive the service: community members must become 'engaged'. In our rural community context, this had particular implications in terms of community dynamics - including long-standing rural residents who resisted the idea of 'businessification' of support services that were already delivered informally by residents and more recent in-migrants who often had almost contrary opinions of a need for the state to 'provide'.

The legitimacy stage was facilitated by the Project Manager who acted as a leader and confidence builder. The Project Manager arranged meetings with community members and other stakeholders, participated informally in community activities in order to build contacts and trust and also met with existing voluntary/community groups that could act as potential focus points for starting a social enterprise.

As the Project Manager built trust within the community, key citizens who were important in relaying information through informal community networks, were identified. If these key citizens were not identified or failed to engage with the concept of co-production then the process of social enterprise creation failed to gain legitimacy within the community. Within such small and dispersed communities, it was not always easy to identify key citizens, particularly those who had time to contribute as many residents were already engaged in high levels of volunteering and civic engagement.

These key citizens were often also important in later stages, e.g. in facilitating community action and initiating/running a community social enterprise. When community members did not 'connect' with the Project Manager and establish trust at this stage, it seriously hampered or broke down the social enterprise development process. The legitimacy stage seems, therefore, necessary in breaking down suspicions surrounding greater involvement of community members in their own service provision and community social enterprises as an organisational form that can deliver services locally. Citizens may not be 
familiar with the concept of identifying need and being involved in co-design and coproduction of services through community social enterprise activities. Therefore, the role of the 'catalyst' figure is to breakdown suspicions within communities so the community social enterprise approach becomes a viable or legitimate one in their eyes. . This stage of the development process involves careful understanding of current community activities, facilitation of community dialogue and the emergence of key citizen actors.

\section{Stage 2-Needs/opportunity recognition}

Facilitated community meetings helped to embed the legitimacy of the 040 concept within each community. This involved processes of community dialogue where the Project Manager spoke to community members discussing the idea of involvement in service design and delivery. This dialogue progressed from one around generating general community 'buy in' to social enterprise to the identification of particular needs or opportunities for service delivery within the community that could be met through social enterprise. If this dialogue fails, and local support is not harnessed around a particular need or opportunity, then a community could lack the catalyst to create a social enterprise.

Within the 040 project, key community representatives engaged in a process of needs/opportunity recognition that was facilitated by the Project Manager. The community social enterprise development process moved forward once this had resulted in a certain level of group consensus over the nature of older people's need within the community and a desire to, collectively, respond to this through socially entrepreneurial activity. Thus, facilitated community meetings provided opportunities for citizens to come together in a process of needs recognition and collective 'buy in' to the idea of translating 'need' into 'action' was required in order to coalescence citizens to take forward community social enterprise creation. This collective needs recognition came in various forms - from identification of unmet need within the community for which a new service was required; to identification of 'embedded' need that had previously been tackled 
through some form of informal help-giving; and identification of crisis points, such as the potential removal of a public sector service.

\section{Stage 3-Group coalescence}

Analysis of the project materials has shown that a prerequisite for rural community social enterprise creation is a collective needs/opportunity identification and a desire to actively address this through social entrepreneurialism. In Stage 3 of the development process, this desire for activity was translated into action through the coming together of several key citizens within each community, alongside the emergence of community leaders. At this point, the 040 Project Manager's role involved a greater amount of mentoring and networking.

In 040 , the community coalescence was hooked around different circumstances, e.g. the completion of group training or winning start-up finance. In the rural context, training opportunities could involve sometimes lengthy travel to urban locations. These things acted as a catalyst for community social enterprise development activities but also a boost to the groups: raising confidence, enthusiasm and feelings of ownership over the initiative. Without this coalescence, it is hard to imagine how the process of community social enterprise creation could have continued.

The process of community social enterprise development demonstrated the importance of the public sector as a key actor in rural social enterprise creation and development. In all the communities, some degree of public sector support for the 040 'service' was also needed for the initiative to succeed. Frequently, for instance, developed services would require to be bought by the public sector, rather than being feasible in a customer-pays model. Therefore, within the coalescence stage of the processes, skills needed to be drawn on in order to embed the legitimacy of the community social enterprise concept with the public sector. Within 040, the Project Manager took on the role of networker; identifying 
key public sector representatives to engage with and 'selling' the concept of community social enterprise provision as a viable option to them. The Project Manager's reports, for example, highlight significant time spent on activities such as promotions and organisations. A failure to embed the legitimacy of community social enterprise with key individuals within the public sector, may have jeopardised the further development of the communities' initiatives.

\section{Stage 4-Organisational establishment}

Although the act of community entrepreneurship was central to the community social enterprise creation process, the Project Manager played an important role in catalysing the process. As the process in the 040 project moved onto Stage 4 and a community social enterprise was established, the Project Manager continued in the role of mentor and networker whilst, at the same time, community members took on increasing levels of responsibility for the tasks and activities associated with the emergent organisation. Nevertheless, within the communities, the presence of the Project Manager as an 'external expert' figure was often valued by the community members and groups; someone from 'outside' or a university was seen as a more credible 'expert' or leader. The Project Manager was often valued as a credible 'outsider' as a catalyst to the process of community social enterprise creation; assisting with business planning and development of a model of community social enterprise that was locally appropriate and acceptable.

This suggests that an external expert may be a key feature of making community social enterprise development work in rural communities. Existing social entrepreneurship theory places importance on the local embededness of entrepreneurial figures; yet the 040 project shows that in remote and rural communities the presence of an external figure can be a positive force in the generation of community social enterprise. However, the Project Manger had to tread a fine line between providing adequate support to the community and taking on too great a role within the community social enterprise process 
- because community members had to take on roles within the social enterprise in order for services to be delivered). The Project Manager had to be able to overcome the aspects that stifle leadership in small communities - such as small, inter-connected populations, conflict and disagreement - but have sufficient connection with the community to be able to understand their needs, draw successfully on social networks and connect resources. 040 suggests that the catalytic figure also needs to be sufficiently distant and 'credible' to command respect through status or connection to a status-full organisation. This raises questions on the one hand about the potentially positive aspects of an external, employed, figure leading community social enterprise creation and on the other hand about how much involvement is too much.

Within Stage 4, the community social enterprise development needs to overcome a difficulty of formalising existing helping within rural communities. The introduction of a 'formalised' model of helping, for example, related to the tension between moving from a community/reciprocity model to a capitalist exchange model of service provision promoted in current policy. In each community there were people tied into informal social networks that provided help, and who were not afraid to ask others for help and had done reciprocal favours. However, there were others who did not have these resources and may not receive informal help. Those who were tied into social networks were hesitant to formalise the current model of help-giving, whereas those who were less tied in are more receptive to the idea. Thus, rural community social enterprises need to cleverly negotiate both unmet need and existing voluntarism - providing services in a way that generates local buy-in but does not damage existing informal supporting structures.

\section{Stage 5-Social enterprise operates}

040 has shown that in remote and rural areas, community social enterprises must bridge civic-public discourses. Commercial-social logics are also bridged when organisations establish service or trading agreements with the public sector. The commercial element of 
a community social enterprise can take different forms and the success of the 040 project's communities seems grounded in the local appropriateness of the service that they chose to delivery and the organisational structure selected. This 'appropriateness' relates to a tension that was experienced in the project communities - that of translating existing voluntarism within rural communities into more formalised participation through a social enterprise model (as mentioned above).

Social entrepreneurs have been identified as needing the skills to bring together both civic and commercial objectives within their organisations (Mair and Marti, 2004; Sharir and Lerner, 2006). In the 040 communities, the social enterprises needed to bridge the civic objectives of community need/desire and the public sector objectives of accessible service provision alongside cost minimisation. Thus, rural community social enterprise leaders need to bridge the discourses of these two sectors and meet the objectives of both through the service delivered and type of organisation created.

Although the Project Manager did much to facilitate the bridging of these logics, sustainability for the community social enterprises came with the Project Manager retreating to the role of distanced advice-giver and, at the same time, citizens taking ownership of the community social enterprise and its service provision. In Stage 5 of the process, community members took on responsibility for their organisations requirements to benefit the community/respond to community need; deliver social value and meet public sector expectations of quality and value. In order to sustain a social enterprise organisation that bridges the civic-public logics, communities need to maintain coalitions with the sections of the public sector that 'support' their organisations (e.g. start-up funding, grants, procurement contracts).

\section{Conclusion: Community Social Enterprise in the Rural Context}

Existing entrepreneurship literature is weighted towards valuing the role of individuals 
within social enterprise development processes. Much research, for example, has centred on the part played by the entrepreneurial figure in generating an idea, designing a business, setting it up and keeping it running (e.g. Parkinson and Howorth, 2008; Steinerowski et al., 2008b). This has been referred to as the "heroic...but solitary social entrepreneur' (Muñoz, 2009). Less attention has been paid to the community social enterprise development that is initiated and sustained by collaborative citizen-based activity; despite the fact that recent policy discourse has promoted this type of social enterprise. Rural areas may both provide conditions suited to community social enterprise and be potentially negatively affected by trends towards a retrenchment of public services and emphasis on community-led provision. The 040 project sought to understand whether community social enterprise could be facilitated in rural areas and analysis of the process carried out in four communities has allowed identification of five key stages of rural community social enterprise development. These have implications for the potential creation (or otherwise) of social enterprises for co-production by other rural communities.

This paper has presented a model of development that reflects the most prevalent themes to emerge from thematic analysis of qualitative case study materials - this illustrates some key considerations for facilitating community social enterprise in other rural locations. For instance, although community action was needed in order to create community social enterprises, the project manager and community members needed to take on some of the skills and roles traditionally attributed to the individual social entrepreneur (Steinerowski et al., 2008b). The 040 process suggests that communities within remote and rural areas need to be able to draw on certain traditional socially entrepreneurial capabilities in order to catalyse the creation of a community social enterprise. Thus, communities need to include individuals with these skills, be able to combine their talents to generate these skills, draw on these skills from elsewhere or be trained to develop these skills. 
Our model of community social enterprise development has shown that a leader(s) in remote and rural communities need to be able to legitimise the idea of community social enterprise for service delivery with both their wider community (including potential service users) and the public sector (including potential commissioners). This reveals the importance of a figure, or figures, who possesses the socially entrepreneurial capability of building 'discursive legitimacy' (Tracey et al., 2008). Such a figure needs to be competent in both the civic discourse of the community (with awareness of local needs, cultures and social value) and the public discourse of the state (with awareness of co-production, procurement and budgeting). They must be competent and confident in shifting between the two and in reconciling their sometimes disparate focuses. Thus, the findings presented in this paper suggest several elements that are important for community social enterprise development within remote and rural communities:

Firstly, community social enterprise must be seen as a legitimate service provider by the communities that they serve and the public sector that provides funding and/or commissions its services. For community social enterprise to occur, citizens need to first engage with the idea of service design and co-production. This suggests that rural community may not contain a pool of people that are ready or willing to engage in the creation of social enterprise for co-produced service delivery. Policy that promotes such an approach will need to consider, therefore, how legitimacy can be fostered in rural communities, and skills built in order to enable rural communities to act together to respond to service delivery challenges through the social enterprise model.

Presented study observed that community engagement in remote and rural areas is about generating enthusiasm but also helping community members to have confidence in their own abilities and develop some of the skills that may be lacking through, e.g. social enterprise training. Legitimacy with the public sector is particularly important in small, often dispersed, remote and rural communities where reliance on public sector grant 
funding and trading agreements is particularly high. In rural areas, funding from the public sector is particularly important and communities often need to know that there will be public sector support for the initiative before it gets off the ground. As Dart (2004) discusses the legitimacy of social enterprise as an organisational model linked to 'probusiness' and 'pro-market' ideologies, so the social enterprise as a provider of services is linked to a legitimisation of social businesses as service providers in both the eyes of those commissioning and receiving the service. This suggests that encouraging social enterprise development for service provision is about more than offering start-up grants and business advice - it needs to be part of a wider process that helps to shift expectations of service provision and the role of the state and Third Sector.

Secondly, for the community social enterprise to occur, community action is needed to create organisations within such small and rural communities. The 040 project has shown that the act of coming together as a community 'group' predicates the emergence of a community social enterprise. However, it also highlights how external facilitation of community entrepreneurship can be a positive force within rural communities. Many of the 040 communities were particularly receptive to what they perceived as a 'credible' outsider or 'expert' to catalyse the community social enterprise establishment process. This raises interesting questions about whether there are ways of, and utility in, promoting greater levels of external facilitation. As communities and social enterprises are asked to take on a bigger role within the design and delivery of services, will some communities be more willing to engage in these processes than others and will this create (new) uneven geographies of service provision?

Thirdly, public sector managers and commissioners need to engage with the idea of working with communities to produce services together, rather than just delivering services to communities. The model of community social enterprise development presented in this paper shows that there is a need for individuals who can bridge the civic 
and public discourses of the community and the state. To some extent this involves employing the "rhetorical strategies" of social entrepreneurship that have been noted elsewhere (Ruebottom, 2011). However, this needs to be in the context of developing a relationship between communities and the public sector that is grounded in honest dialogue and acceptance of each other's strengths, weaknesses and limitations. It also involves the creation of social enterprises that negotiate a delicate balance between unmet need and existing informal helping structures within rural communities.

Summarising, this paper has shown that community social enterprise for service provision in rural areas can be supported and developed through a facilitated community development approach. The analysis of the approach taken has identified several key features that may be applied to wider facilitation of community social enterprise in other rural areas including the role of the catalytic 'outsider'; engagement with appropriate training opportunities; early engagement with the public sector and commissioners and drawing on the traditions of local voluntarism.

\section{Acknowledgments}

This research contributes to the Scottish Government-commissioned Strategic Research Programme, "Governance and Decision-Making for Community Empowerment" (20112016).

\section{References}

Anderson, A. and Jack, S. (2002) The articulation of social capital in entrepreneurial networks: a glue or a lubricant?, Entrepreneurship \& Regional Development, 14, 193-210.

Bertotti, M., Harden, A., Renton, A. and Sheridan, K. (2012) The contribution of a social enterprise to the building of social capital in a disadvantaged urban area of London, Community Development Journal, 47(2), 168-183. 
Boyle, D., Harris, M., (2009) The Challenge of Co-Production, London, NEF, the Lab and NESTA.

Boyle, D., Coote, A., Sherwood, Ch. and Slay, J. (2010) Right Here, Right Now. Taking co-production into the mainstream, London, NESTA.

Cabinet Office (2010) Building the Big Society, Cabinet Office. accessed at: http://www.cabinetoffice.gov.uk/media/407789/building-big-society.pdf $\quad$ (30 October 2010).

The Conservative Party (2010) Big Society, Not Big Government: Building a big Society, Conservatives, London.

Dale, A. and Onyx, J. (2005) A dynamic balance: social capital and sustainable community development, Vancouver, UBS Press.

Dart, R. (2004) The Legitimacy of Social Enterprise, Nonprofit Management and Leadership, 14(4), 411-424.

DeVasconcelos, A. and Lezana, A. (2012) 'Model of life cycle of social enterprises', Revista de Administracao Publica, 46(4), 1037-1058.

Department of Trade and Industry (2002) Social enterprise: a strategy for success, London, DTI.

Department of Trade and Industry (2006) A social enterprise strategy for Scotland: a consultation, London, DTI.

Farmer, J., Steinerowski, A. and Jack, S. (2008) Starting social enterprises in remote and rural Scotland: best or worst of circumstances?, The International Journal of Entrepreneurship and Small Business, 6(3), 450-464.

Fletcher, D.E. (2006) Entrepreneurial processes and the social construction of opportunity, Entrepreneurship \& Regional Development, 18, 421-440.

Hines, F. (2005) Viable Social Enterprise: an evaluation of business support to social enterprises, Social Enterprise Journal, 1(1), 13-28. 
Kerlin, J. (2006) Social Enterprise in the United States and Europe: understanding and learning from the differences, Voluntas, 17(3), 246-262.

Ko, S. (2012) Viability of social enterprises: the spillover effect, Social Enterprise Journal, 8(3), 251-263

Koshy, V. (2009) Action Research for Improving Educational Practice: a step-by-step guide, London, Sage.

Liu, G. and Ko, W-W. (2012) Organisational learning and marketing capability development: a study of the charity retailing operations of British social enterprise, Nonprofit and Voluntary Sector Quarterly, 41(4), 580-608

Mair, J. and Marti, I. (2004) Social entrepreneurship research: a source of explanation, prediction and delight, Journal of World Business, 41(1), 36-44.

Muñoz, S. (2009) Towards a geographical research agenda for social enterprise, Area, 42(3), 302-312.

Needham, C. (2007) The reform of public policy under New Labour: narratives of consumerism, Basingstoke, Palgrave MacMillan.

Nguyen, M., Rohe, W., and Cowan, S. (2012) Entrenched hybridity in public housing agencies in the USA, Housing Studies, 27(4), 457-475.

OECD (2008) Rural Policy Reviews: Scotland, UK - Assessment and Recommendation, OECD.

Ogilvie, R. (2012) Community Development Approaches to Improving Public Health, Routledge.

O’Shayghnessy, M., Casey, E., Enright, P. (2011) Rural transport in peripheral rural areas: the role of social enterprises in meeting the needs of rural citizens', Social Enterprise Journal, 7(2), 183-190.

Parkinson, C. and Howorth, C. (2008) The language of Social Entrepreneurs, Entrepreneurship \& Regional Development, 20(May), 285-309. 
Ples, N., M., Appel, J. (2012) In Pursuit of Dignity and Social Justice: changing lives through 100\% inclusion - how Gram Vikas fosters sustainable rural development', Journal of Business Ethics, 111(3), 389-411.

Phillips, M. (2006) Gowing Pains: the sustainability of social enterprise, International Journal of Entrepreneurship and Innovation, 7(4), 221-230.

Ridley-Duff, R. (2007) Social enterprise as a socially rational business, International Journal of Entrepreneurial Behaviour \& Research, 14(5), 291-312.

Ruebottom, T. (2011) The microstructures of rhetorical strategy in social entrepreneurship: building legitimacy through heroes and villains, Journal of Business Venturing, article in press.

Scottish Executive (2007) All our futures: planning for a Scotland with an Ageing Populatio, Edinburgh, Scottish Executive.

Sharir and Lerner (2006) Gauging the success of social ventures initiated by individual social entrepreneurs, Journal of World Business, 41(1), 6-20.

Steiner, A. and Markantoni, M. (2013) Exploring Community Resilience in Scotland through Capacity for Change. Community Development Journal, August, 1-19.

Steinerowski, A., Jack, S. and Farmer, J. (2008b) Who are the social entrepreneurs and what do they actually do?, Frontiers of Entrepreneurship Research, 693-708.

Steinerowski, A., Jack, S. and Farmer, J. (2008a) Social entrepreneurship in a rural context: an over-ideological 'state'?, Journal of Rural Enterprise and Management , 4(1), 20-39.

Simmons, R. (2008) Harnessing Social Enterprise for Local Public Services: the case of new leisure trusts in the UK, Public Policy and Administration, 23(3), 278-301.

Teasdale, S. (2012) Negotiating tensions: how do social enterprises in the homelessness field balance social and commercial considerations? Housing Studies, 27(4), $514-532$. 
Thompson, J., (2011) 'Reflections on social enterprise and the Big Society', Social Enterprise Journal, 7(3), 219-223.

Torri, M.C. (2012) Community gender entrepreneurship and self-help groups: a way forward to foster social capital and truly effective forms of participation among rural poor women? Community Development Journal, 47(1), 58-76.

Tracey, P., Phillips, N. and Haugh, H. (2005) Beyond Philanthropy: Community Enterprise as a Basis for Corporate Citizenship, Journal of Business Ethics, 58(4), 327-344.

Whitehead, J. and McNiff, J. (2001) Action Research: Principles and Practice, Routledge.

Zahra, S., Gedojlovic, E., Neubaum, D.O., Shulman, J.M. (2009) A typology of social entrepreneurs: motives, search processes and ethical challenges, Journal of Business Venturing, 24(5), 519-532.

Zografos, Ch. (2007) Rurality discourses and the role of the social enterprise in regenerating rural Scotland, Journal of Rural Studies, 23(1), 38-51. 
Appendix 1

\begin{tabular}{|c|c|c|c|c|c|}
\hline & Stage 1 & Stage 2 & Stage 3 & Stage 4 & Stage 5 \\
\hline 胥 & $\begin{array}{l}\text { Initial difflicultes in generating } \\
\text { enthusiasm towards } 040 \text { concept } \\
\text { Some community members like } \\
\text { the idea of an oral history project }\end{array}$ & $\begin{array}{l}\text {-Using a council grant community } \\
\text { members buy a video camera and } \\
\text { editing equipment } \\
\text { - Community obtains advice and } \\
\text { training about fllming and } \\
\text { interviewing from experts }\end{array}$ & $\begin{array}{l}\text { Local oider people interview other } \\
\text { older people in the village about } \\
\text { early memories and life in the past } \\
\text { - Interviews are edited by a local } \\
\text { volunteers } \\
\text {-A heritage community DVD is } \\
\text { produced }\end{array}$ & $\begin{array}{l}\text { Older people involved in the profect report } \\
\text { becoming more confident and that a 'sense of place' } \\
\text { has developed }\end{array}$ & $\begin{array}{l}\text {-The oral history group work with others in } \\
\text { the community to develop plans to run the } \\
\text { village hall as a cafe and heritage centre } \\
-040 \text { supports setting up a new social } \\
\text { enterprise attracting a package of funding } \\
\text { ( } 225,000 \text { ) to test the feasibility of developing } \\
\text { seivices in the village hall } \\
\text {-A hall is beling transferred to community } \\
\text { ownership from the local authority }\end{array}$ \\
\hline 耀 & $\begin{array}{l}\text {-The community engaged with the } \\
\text { concept of } 040 \text { quickly as a } \\
\text { potential way to moet the percelved } \\
\text { pressing need of transport } \\
\text { provision for older people in the } \\
\text { area }\end{array}$ & $\begin{array}{l}\text { A subgroup of a local community } \\
\text { development company is established. } \\
\text { A key local figure emerges in a } \\
\text { leadership capacity and draws in } \\
\text { further local volunters }\end{array}$ & $\begin{array}{l}\text { A rapidly prepared application for } \\
\text { funding is prepared in response to a } \\
\text { call for Community Transport } \\
\text { Grants. The group aims to provide } \\
\text { door-to-door transport for local } \\
\text { older people }\end{array}$ & $\begin{array}{l}\text { The Community Transport Grant is awarded } \\
\text {-In developing the transport organisation, a more } \\
\text { complex model evolves that incorporates the } \\
\text { varying needs of oider people and ways that they are } \\
\text { comfortable with accessing a traneport scheme }\end{array}$ & $\begin{array}{l}\text { The group takes ownership of two vehicles } \\
\text { and engage in business planning and in } \\
\text { restructuring in response to growth. } \\
\text { A range of services are developed: an } \\
\text { informal litt sharing scheme; a community } \\
\text { car scheme; a demand responsive transport } \\
\text { scheme }\end{array}$ \\
\hline 晃 & $\begin{array}{l}\text { Community members quickly } \\
\text { engage with } 040 \text { as a way to } \\
\text { address a long standing percetved } \\
\text { meed within the community - to } \\
\text { maintain a residential care service } \\
\text { for older people, as this is threaten } \\
\text { by public service withdrawal }\end{array}$ & $\begin{array}{l}\text {-The } 040 \text { Project Manager is imvolved } \\
\text { in researching models of care in other } \\
\text { remote and rural communities and } \\
\text { informattion about the resources } \\
\text { required to establish and maintain a } \\
\text { new service This informs discussions } \\
\text { with the community about ideas for a } \\
\text { service within their area }\end{array}$ & $\begin{array}{l}\text { The } 040 \text { Project Manager suggests } \\
\text { soclal enterprise training to the } \\
\text { community group. There is some } \\
\text { reluctance and the Project Manager } \\
\text { negatiates for the training to be } \\
\text { delivered in a locally accessible } \\
\text { venue, at a convenient time, and } \\
\text { with the tutle and content adapted to } \\
\text { be appealing to community } \\
\text { members }\end{array}$ & $\begin{array}{l}\text {-Due to local authority cuts in service provision, the } \\
\text { focus of the commmunity changes from trying to } \\
\text { develop an ideal model of residential care to } \\
\text { establishing a sustainable model which could reduce } \\
\text { the impact of an Imminent service cut } \\
\text { - Key community members are prepared to drive } \\
\text { forwand the process } \\
\text { - The community approach the councill with a } \\
\text { proposal to take over the running of the local centre } \\
\text { to be clased, which the councll aceept }\end{array}$ & $\begin{array}{l}\text {-A community interest company is } \\
\text { established and pald by the council to take } \\
\text { over ruming of the centre }\end{array}$ \\
\hline$\frac{\overrightarrow{\mathrm{D}}}{\mathrm{g}}$ & $\begin{array}{l}\text {-The } 040 \text { Project Manager meets } \\
\text { local comimunity members and } \\
\text { suggests that a service providing } \\
\text { low level household and DIY tasks } \\
\text { delivered to older people may be } \\
\text { benefletal to the area }\end{array}$ & $\begin{array}{l}\text {-Various factor contribute to a lack of } \\
\text { engagement in the development } \\
\text { process by community members, } \\
\text { including a dispersed population and } \\
\text { lack of local leaders to drive action } \\
\text { forward }\end{array}$ & $\begin{array}{l}\text { Local people decide aganst the idea } \\
\text { for the development of a } \\
\text { melighbourly helping service and opt } \\
\text { to lobby for an enhancement of the } \\
\text { Handy Person service currently } \\
\text { funded by the local authority in a } \\
\text { melighbouringarea }\end{array}$ & The development process is not taken forward & $\begin{array}{l}\text { A community soctal enterprise is not } \\
\text { established }\end{array}$ \\
\hline
\end{tabular}

